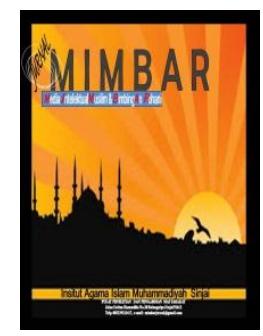

Volume 7, No. 2, 2021

ISSN (print) : 2442-3217 / ISSN (online) : 2716-3806

Email : mimbarjurnal@gmail.com

Homepage : http://journal.iaimsinjai.ac.id/indeks.php/mimbar

DOI $\quad$ : https://doi.org/10.47435/mimbar.v7i2

\title{
EKSISTENSI KECENDERUNGAN MEMILIKI DALAM ISLAM
}

\author{
Amir Hamzah ${ }^{1}$, Nurasmi ${ }^{2}$ Mutmainnah ${ }^{3}$ \\ ${ }^{1}$ Institut Agama Islam Muhammadiyah Sinjai, Sulawesi Selatan \\ ${ }^{1}$ Email: Amirhamzah1213@gmail.com \\ ${ }^{2}$ Email: nurazmii021@gmail.com \\ ${ }^{3}$ Email: mutmainnahnur80@gmail.com
}

\begin{abstract}
Humans as a bearing creature have a veriety of potential and tendency in it self that is a fitrah human. One of the laeries owned almost all human beings are a nature tendency like towards worldly like, treasure, thornes, couples, and families. This part of the nature of the human God who gives to them. According to the Koran, Alloh is the absolute owner of wealth. Wealth as private asset is intended for direct human character and attitude to look for, own, and use it on the right path. Wealth as belonging together meant that all humans have the opportunity to look for wealth, no one is given the right to strict circulation of wealth in the human environment and in every one's wealth there are parts of others. The method used in this journal is descriptive that presents a description is and more profound analysis because the object of review is only in verses then the appropriate approach is the Tafsir Maudhu'i. Function of wealth as a provision for worship, support life, as aztest of faith, the support to be a leader, and one of the jewelry of life. Obtaining wealth should not be by way of vanity, its use must be balanced, the management must be careful, honest, sincere, and transparent and able to provide benefits to the community. Therefore it is necessary to have rules that regulate human needs so as not to violate and control the rights of others, especially related to property and ownership in islam.
\end{abstract}

Keywords: Tendencyes, have in islam.

\section{Abstrak}

Manusia sebagai makhluk berakal memiliki berbagai potensi dan kecenderungan dalam dirinya yang merupakan suatu fitrah manusia. Salah satu kecondongan yang dimiliki hampir seluruh manusia adalah kecenderungan alamiah seperti terhadap duniawi seperti harta, tahta, pasangan, dan keluarga. Ini merupakan bagian dari sifat alamiah manusia yang diberikan Allah swt kepada mereka. Menurut Al-Qur'an, Allah adalah pemilik mutlak harta. Harta sebagai milik pribadi seseorang dimaksudkan untuk mengarahkan sifat dan sikap manusia dalam mencari, memiliki, dan memgunakannya pada jalan yang benar. Harta sebagai milik bersama dimaksudkan bahwa semua manusia memiliki kesempatan untuk mencari harta, tidak seorangpun diberikan hak untuk mempersempit peredaran harta dalam lingkungan manusia, dan dalam setiap harta seseorang, terdapat bagian orang lain. Metode yang digunakan pada junal ini adalah deskriptif yaitu menyajikan deskripsi sebagaimana adanya dan analisa lebih mendalam, karena objek kajiannya hanya pada ayat-ayat maka pendekatan yang tepat adalah tafsir maudhu'i. Fungsi harta sebagai ibadah, penunjang kehidupan, sebagai ujian keimanan, pendukung untuk menjadi pemimpin, dan salah satu perhiasan hidup. Memperoleh harta tidak boleh dengan cara yang salah, penggunaannya harus seimbang, pengelolaannya harus cermat, jujur, ikhlas, dan transparan dan mampu memberi manfaat bagi masyarakat. Oleh karena itu perlu adanya aturan yang mengatur kebutuhan manusia agar tidak melanggar dan menguasai hak orang lain, khususnya terkait dengan harta dan kepemilikan dalam islam.

Kata Kunci: Kecenderungan, Memiliki dalam islam.

MIMBAR : Jurnal Media Intelektual Muslim dan Bimbingan Rohani

Olicensed under a Creative Commons Attribution-ShareAlike 4.0 International License 


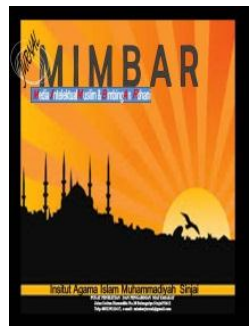

\section{MIMBAR}

Jurnal Media Intelektual Muslim dan Bimbingan Rohani

Volume 7, No. 2, 2021

ISSN (print) : 2442-3217 / ISSN (online) : 2716-3806

Email : : mimbarjurnal@gmail.com

Homepage : http://journal.iaimsinjai.ac.id/indeks.php/mimbar

DOI $\quad$ : https://doi.org/10.47435/mimbar.v7i2

\section{Pendahuluan}

Manusia sebagai makhluk sosial pada prinsipnya selalu ingin hidup bermasyarakat. Dalam kehidupan bermasyarakat, manusia akan menghadapi berbagai macam persoalan untuk menutupi kebutuhan antara yang satu dengan yang lain, sehingga dibutuhkan sikap saling tolong-menolong. Setiap individu pada dasarnya mengalami ketergantungan pada nilai-nilai kemanusiaan dan keberadaanya dalam suatu kelompok (HD, 2000).

Ketergantungan seseorang dikarenakan setiap manusia mempunyai kebutuhan. Kebutuhan yang harus dipenuhi oleh ekonomi itu berbeda dari masyarakat yang satu ke masyarakat yang lain, dari orang yang satu ke orang yang lain. Perbedaan itu disebabkan oleh berbagai faktor, salah satunya sesuai kebutuhan (Wiranegara, 1988). Ajaran islam merupakan ajaran yang sempurna mencakup seluruh kehidupan maka kita wajib berpendirian bahwa islam sebagai agama yang telah menggariskan prinsip-prinsip kehidupan mencakup berbagai aspek, termasuk aspek kecenderungan memiliki.

Islam memelihara keseimbanga anatar hak milik pribadi dan kolektif sehingga islam menjamin pembagian kekayaan yang seluas-luasnya dan paling bermanfaat melalui lembaga-lembaga yang didirikan (Mannan, 1993). Permasalahannya banyak yang belum memahami bagimana islam memandang harta dan kepemilikan.

Harta merupakan salah satu penopang hidup yang dibutuhkan manusia dalam menjalankan aktifitasnya didunia. Untuk mewujudkan kemashalatan dan menolak kemudharataan dalam mencapai kebahagiaan didunia dan diakhirat, maka salah satu yang harus dijaga adalah harta (hifz al-mal). Karena itu, tidak satupun manusia yang dapat menjalankan hidupnya tanpa dibarengi dengan harta. Banyak sekali ketimpangan yang dialami manusia sebagai akibat kekurangan harta. Aspek-aspek yang dianggap berpangkal dari kekurangan material tersebut mencakup berbagai aspek kehidupan seperti kelaparan, kebodohan, maraknya kriminalitas, rendahnya kesehatan, dan lainnya. Oleh sebab itu, tidak dipungkiri bahwa harta merupakan salah satu aspek yang harus mendapat perhatian penting bagi setiap umat islam. 


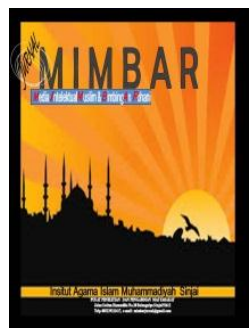

\section{MIMBAR}

Jurnal Media Intelektual Muslim dan Bimbingan Rohani

Volume 7, No. 2, 2021

ISSN (print) : 2442-3217 / ISSN (online) : 2716-3806

Email : : mimbarjurnal@gmail.com

Homepage : http://journal.iaimsinjai.ac.id/indeks.php/mimbar

DOI $\quad$ : https://doi.org/10.47435/mimbar.v7i2

Pada sisi lain, manusia dihadapkan kepada persoalan bagaimana dan dimana memperoleh harta yang dimaksud. Persoalan ini merupakan siklus yang tidak pernah terputus yang sangat dipengaruhi oleh latar belakang pendidikan, keterampilan, fisik, keturunan, dan kondisi lingkungan yang dihadapi seseorang. Tidak sedikit manusia yang harus bekerja keras untuk memperoleh harta yang dibutuhkan, walaupun kadangkala hasil yang diperoleh tidak setimpal dengan tenaga ia dikeluarkan. Sebaliknya, sebagai manusia cukup mengeluarkan sedikit tenaga atau bahkan tidak perlu mengeluarkan sedikit pun tenaga untuk memperoleh harta yang banyak. Fenomena seperti ini, tentu sangat dipengaruhi oleh jenis profesi yang digeluti seseorang.

Islam memelihara keseimbangan antara hak milik pribadi dan kolektif sehingga Islam menjamin pembagian kekayaan yang seluasluasnya dan paling bermanfaat melalui lembaga-lembaga yang didirikan. Permasalahanya banyak yang belum memahami bagaimana islam memandang harta dan kepemilikan (Mannan, 1993).

Sejatinya semakin tinggi tingkat intelektualitas seseorang, maka semakin sedikit tenaga yang harus dikeluarkan untuk mendapatkan harta yang dibutuhkan. Begitulah gambaran tentang kecenderungan memiliki yang tidak pernah habis bila dikupas dalam berbagai aspeknya. Oleh karena itu penulis membahas kepemilikan dengan judul "Eksistensi Kecenderungan Memiliki dalam Islam”.

\section{Metode}

\section{Pembahasan}

\subsection{Hakikat Kecenderungan memiliki}

\subsubsection{Definisi Kecenderungan Memiliki}

Secara etimologi memiliki berasal dari bahasa arab yaitu Al-Milku (milik) yang berarti kepemilikan. Dalam istilah Al-Milku secara bahasa berarti penguasaan terhadap sesuatu, atau sesuatu yang dimiliki. Manusia sebagai makhluk berakal memiliki berbagai potensi dan kecenderungan dalam dirinya yang merupakan suatu fitrah manusia, baik yang bersifat positif maupun negatif. Salah satu kecondongan 


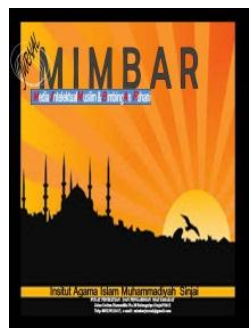

\section{MIMBAR}

Jurnal Media Intelektual Muslim dan Bimbingan Rohani

Volume 7, No. 2, 2021

ISSN (print) : 2442-3217 / ISSN (online) : 2716-3806

Email : : mimbarjurnal@gmail.com

Homepage : http://journal.iaimsinjai.ac.id/indeks.php/mimbar

DOI $\quad$ : https://doi.org/10.47435/mimbar.v7i2

yang dimiliki hampir seluruh manusia adalah kecenderungan alamiah seperti terhadap duniawi seperti harta, tahta, pasangan, dan keluarga. Ini merupakan bagian dari sifat alamiah manusia yang diberikan Allah swt kepada mereka. Kecenderungan memilik dapat diartikan sebagai kecondongan, keinginan atau kesukaan manusia yang mengarah pada suatu hal seperti keinginan untuk memilki harta benda yang berlimpah.

Dalam fiqh muamalah al-Milku didefenisikan sebagai Kekhususan terhadap pemilik suatu barang menurut syara' untuk bertindak secara bebas bertujuan mengambil manfaatnya selama tidak ada penghalang syar'i. Makna yang sama juga dijelaskan oleh Rawwas Qal'ah Jie bahwa kepemilikan berarti hubungan syriah antara manusia dengan sesuatu (harta) yang memberikan hak mutlak kepada orang itu untuk melakukan pemanfaatan (tasharruf) atas sesuatu itu dan mencegah orang lain untuk memanfaatkannya (Qalaji et al., 1996). Apabila seseorang telah memiliki suatu benda yang sah menurut syara', maka orang tersebut bebas bertindak terhadap benda tersebut, baik akan dijual maupun akan digadaikan, baik dia sendiri maupun dengan perantara orang lain (Qordaw, 2007).

Menurut istilah al-milku dapat didefinisikan "suatu ikhtishas yang menghalangi yang lain, menurut syariat yang membernarkan pemilik ikhtishas itu untuk bertindak terhadap barang miliknya sekehendaknya kecuali ada penghalang (Al-Zarqa, 1968). Sedangkan Wahbah al Zuhaily mendefinisikan bahwa al-milku adalah Milik adalah keistimewaan (ikhtishash) terhadap sesuatu yang menghalangi orang lain darinya dan pemiliknya bebas melakukan tasharruf secara langsung kecuali ada halangan syar'I (Al-Zuhaily, 1989).

Secara terminology, definisi al-milku yang dikemukakan oleh para fukaha. Whbah al-Zuhaily memberikan definisi al-milku yaitu: "Hak kepemilikan ialah sesuatu kekhususan terhadap sesuatu harta yang menghalangi orang lain dari harta tersebut. Pemiliknya bebas melakukan tasharruf kecuali ada halangan syar'i““.

Disinilah kita temukan bahwa ketika Allah SWT menjelaskan tentang status asal kepemilikan harta kekayaan tersebut, Allah SWT menytakan "Maalillah" (harta 


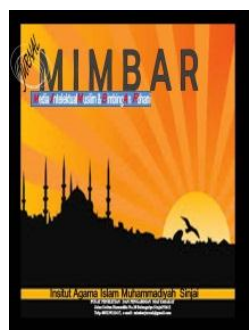

\section{MIMBAR}

Jurnal Media Intelektual Muslim dan Bimbingan Rohani

Volume 7, No. 2, 2021

ISSN (print) : 2442-3217 / ISSN (online) : 2716-3806

Email : : mimbarjurnal@gmail.com

Homepage : http://journal.iaimsinjai.ac.id/indeks.php/mimbar

DOI $\quad:$ https://doi.org/10.47435/mimbar.v7i2

kekayaan milik Allah). Sementara ketika Allah menyadarkan kepemilikan tersebut kepada manusiam maka Allah menyadarkan kepemilikan tersebut kepada manusia. Dimana Allah SWT menyatakan dengan firmannya:

“Maka berikanlah kepada mereka harta-hartanya”. (QS. An-Nisa' : 6)

“Ambilah dari harta-harta mereka”. (QS. Al-Baqarah: 279)

Menurut Syaikh Taqiyuddin an-Nabhani ada tiga macam kepemilikan yaitu:

1) Kepemilikan Individu (Milkiyah Fardhiah)

Adalah idzin para individu untuk memanfaatkan suatu barang melaui lima sebab kepemilikan (asbab al-tamalluk) individu yaitu 1) Bekerja (al-'amal), 2) Warisan (al-irts), 3) Keperluan harta untuk mempertahankan hidup, 4) Pemberian negara (I'hau al-daulah) dari hartanya untuk kesejahteraan rakyat berupa tanah pertanian, barang dan uang modal, 5) Harta yang diperoleh individu tanpa berusaha seperti hibab, hadiah, wasiat,diat, mahar, barang temuan, santunan untuk khalifah atau pemegang kekuasaan pemerintah

2) Kepemilikan Umum (Milikiyah 'Ammah)

Adalah idzin syariat kepada masyarakat secara bersama-sama memanfaatkan suatu kekayaan yang berupa barang-barang yang mutlak diperlukan manusia dalam kehidupan sehari-hari seperti air, sumber energy, hasil hutan, barang tidak mungkin dimiliki individu seperti suangai, pelabuhan, jalan raya, lautan dan sebagainya. Dan barang yang menguasai hajat hidup orang banyak seperti emas, perak minya dan sebagainya.

3) Kepemilikan Negara (Milikiyah Daulah)

Adalah idzin syariat atas setiap harta yang hak pemanfaatannya berada di tangan khalifah sebagai kepala negara. Termasuk dalam kategori ini adalah harta ghanimah (rampasan perang), harta rikaz (harta temuan), harta yang tidak memiliki ahli waris dan tanah milik negara.

Menurut Taqyudin an-Nabani dikatakan bahwa sebab-sebab kepemilikan seseorang atas atas suatu sebab diperoleh melalui: Pertama pekerjaan, kedua warisan, ketiga kebutuhan akan harta yang menyambung hidup, keempat harta pemberian 


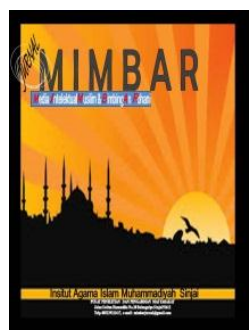

Jurmal Media Intelektual Muslim dan Bimbingan Rohani

Volume 7, No. 2, 2021

ISSN (print) : 2442-3217 / ISSN (online) : 2716-3806

Email : : mimbarjurnal@gmail.com

Homepage : http://journal.iaimsinjai.ac.id/indeks.php/mimbar

DOI $\quad$ : https://doi.org/10.47435/mimbar.v7i2

negara yang diberikan kepada rakyat, kelima harta yang diperoleh seseorang tanpa mengeluarkan harta atau tenaga apapaun (Al-Zuhaily, 1989).

Pada dasarnya, kecenderungan alamiah trhadap duniawi bukanlah suatu hal yg negative, bahkan itu bersifat positif jika diarahkan sesuai tuntunan Allah swt melalui Al-Qur'an dan sabda nabi Muhammad saw. Namun jika kecenderungan tersebut tidak dikelola dengan baik, maka ia bisa saja mendatangkan malapetakan bagi manusia baik di dunia maupun di akhirat kelak.

\subsubsection{Hakikat Kecenderungan Memiliki}

Sebagaimana yang telah diuraikan sebelumnya bahwa fokus kajian kecenderungan memiliki dalam tulisan ini mengarah pada terma al-milku yang berasal dari kata "milik". Maka, untuk mengetahui makna yang terkandung didalamnya, terlebih dahulu perlu dilacak kata ini melalau asal kalimatnya dilacak kata ini melalau asal kalimatnya menggunakan kitab mufahras li al-fadzi al-Qur'an untuk mengetahui ayat-ayat yang menggunakan term tersebut dalam al-Qur'an.

Kata al-milku dengan seluruh bentuk derivasinya di dalam al-Qur'an yang terulang sebagimana berikut:

1) Ditinjau dari aspek makkiyah dapat dilihat dari susunan berikut:
a) Al-A'raf sebanyak 3 kali
b) Al-Isra' sebanyak 4 kali
c) Ar-Ra'd sebanyak 1 kali
d) Al-khaf sebayak 5 kali
e) Maryam sebanyak 1 kali
f) Al-Mu'minun sebanyak 1 kali
g) Saba' sebanyak 2 kali
h) Al-Ma'arij sebanyak 3 kali
i) Nuh sebanyak 2 kali
j) Al-Fajr sebanyak 1 kali

2) Ditinjau dari aspek madaniyah dapat dilihat dari susunan berikut:

a) Al-Baqarah sebanyak 1 kali 
Volume 7, No. 2, 2021

ISSN (print) : 2442-3217 / ISSN (online) : 2716-3806

Email : mimbarjurnal@gmail.com

Homepage : http://journal.iaimsinjai.ac.id/indeks.php/mimbar

DOI $\quad:$ https://doi.org/10.47435/mimbar.v7i2

b) Ali-Imran sebanyak 2 kali

c) Al-Maidah sebanyak 1 kali

d) Al-Anfal sebanyak 2 kali

e) At-Taubah sebanyak 3 kali

f) Al-Ahzab sebanyak 1 kali

g) Al-Mujadilah sebanyak 1 kali

h) Al-Munafiqun sebanyak 1 kali

i) At-Taghabun sebanyak 1 kali

Demikianlah ayat-ayat yang ditunjukan dalam kitab Mu'jam mufahras al-Qur'an dari kata al-milku yang diklasifikasikan melalui penggunaan terma almilku dari asal kata "milik"dalam al-Qur'an.

\subsubsection{Klasifikasi Ayat}

Dari ayat diatas ditemukan beberapa ayat yang menurut penulis dapat dihubungkan dengan kecenderungan memiliki adalah sebagai berikut:

a. Q.S Ali-Imran/3 ayat 14 :

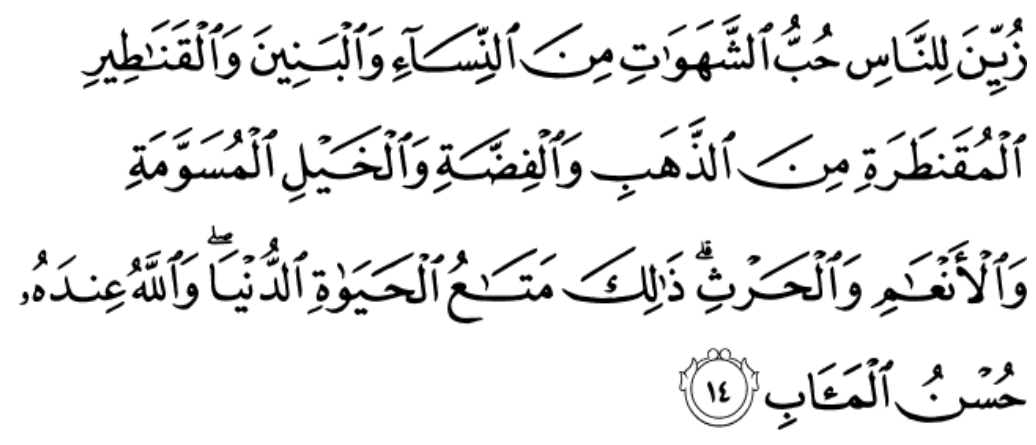

Terjemahan: Dijadikan terasa indah dalam pandangan manusia cinta terhadap apa yang diinginkan, berupa perempuanperempuan, anak-anak, harta benda yang bertumpuk dalam bentuk emas dan perak, kuda pilihan, hewan ternak, dan sawah ladang. Itulah kesenangan hidup di dunia, dan di sisi Allah-lah tempat kembali yang baik. (Kementerian Agama, 2014)

Tafsir: (Dijadikan indah pada pandangan manusia kecintaan kepada syahwat) yakni segala sesuatu yang disenangi serta diinginkan nafsu sebagai cobaan dari Allah 


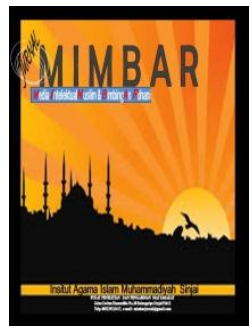

\section{MIMBAR}

Jurmall Media Intelektual Muslim dan Bimbingan Rohani

\section{Volume 7, No. 2, 2021}

ISSN (print) : 2442-3217 / ISSN (online) : 2716-3806

Email : mimbarjurnal@gmail.com

Homepage : http://journal.iaimsinjai.ac.id/indeks.php/mimbar

DOI $\quad$ : https://doi.org/10.47435/mimbar.v7i2

atau tipu daya dari setan (yaitu wanita-wanita, anak-anak,dan harta yang banyak) yang berlimpah dan telah berkumpul (berupa emas, perak, kuda) atau baik binatang ternak yakni sapi dan kambing (dan sawah ladang) atau tanam-tanaman. Demikian itu yakni yang telah disebutkan tadi merupakan kesenangan dunia, di dunia manusia hidup bersenag-senag dengan hartanya, tetapi kemudian lenyap atau pergi (dan di sisi Allahlah tempat kembali yang baik) yakni surga, sehingga itulah yang seharusnya menjadi idaman dan bukan yang lainnya (Tafsir, n.d.).

Dalam ayat ini Allah SWT menyampaikan bahwasannya Dia telah menghiasi hidup manusia sebagai ujian bagi mereka dengan kecintaan pada kesenangankesenangan duniawi, seperti wanita, anak laki-laki, harta yang banyak dan berlimpah berupa emas dan perak, kuda yang bertanda lagi bagus, binatang ternak berupa unta, sapi dan kambing, dan pertanian. Itu adalah kesenanggan hidup di dunia yang bisa dinikmati dalam jangka waktu tertentu kemudian hilang. Maka tidak sepatutnya seorang mukmin menggantungkan hidupnya pada kesenangan tersebut. Hanya Allah saja yang memiliki tempat kembali yang baik, yaitu surge yang luas seluas langit dan bumi.

b. Q.S Al-Khaafi/18 ayat 46 :

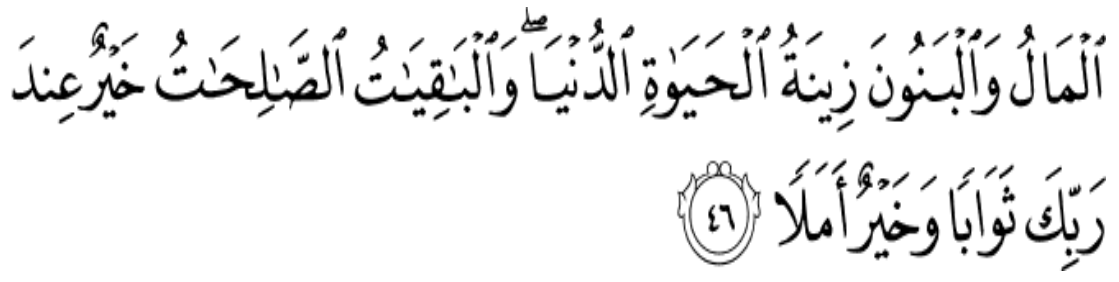

Terjemahan: Harta dan anak-anak adalah perhiasan kehidupan dunia tetapi amal kebajikan yang terus-menerus adalah lebih baik pahalanya di sisi Tuhanmu serta lebih baik untuk menjadi harapan.(Kementerian Agama, 2014)

Tafsir: (Harta dan anak-anak adalah perhiasan kehidupan dunia) keduanya dapat dijadikan sebagai perhiasan didalam kehidupan dunia (tetapi amalan-alamalan yang kekal lagi saleh) yaitu mengucapkan kalimat: Subhaanallah Wal Hamdulillah 


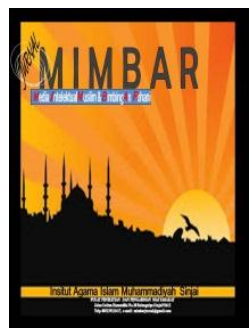

\section{MIMBAR}

Jurnal Media Intelektual Muslim dan Bimbingan Rohani

Volume 7, No. 2, 2021

ISSN (print) : 2442-3217 / ISSN (online) : 2716-3806

Email : : mimbarjurnal@gmail.com

Homepage : http://journal.iaimsinjai.ac.id/indeks.php/mimbar

DOI $\quad$ : https://doi.org/10.47435/mimbar.v7i2

Wa La Ilaaha Illallah Wallaahu Akbar; menurut sebagian ulama ditambahkan Walaa Haulaa Walaa Quwwara Illaa Billaahi (adalah lebih baik pahalanya di sisi Rabbmu serta lebih baik untuk menjadi harapan) hal yang diharap-harapkan dan menjadi dambaan manusi d sisi Allah swt (Tafsir, n.d.).

Dalam ayat ini Allah telah menjelaskan yang menjadi kebanggaan manusia di dunia ini ialah harta benda dan anak-anak, karena manusia sangat memperhatikan keduanya. Banyak harta dan anak dapat memberikan kehidupan dan martabat yang terhormat kepada orang yang memilikinya. Karena itu, harta dan anak dapat menjadikan seseorang takabur dan merendahkan orang lain. Allah menegaskan bahwa keduanya hanyalah perhiasan dalam hidup duniawi bukanlah perhiasan dan bekal untuk akhirat. Padahal manusia sudah menyadari bahwa keduanya akan segera binasa dan tidak patut dijadikan bahan kesombongan. Ayat ini juga menjelaskan bahwa yang patut dibanggakan hanyalah amal kebajiakan yang hasilnya dirasakan oleh manusia sepanjang zaman sampai akhirat. Amal kebaikan lebih baik pahalannya di sisi Allah dibandingkan harta dan anak-anak yang jauh dari petunjuk Allah, dan tentu menjadi pemberi syafaat bagi orang yang memilikinya di hari akhirat kelak ketika harta dan anak tidak lagi bermanfaat.

c. Q.S Al-Fajr/89 ayat 20:

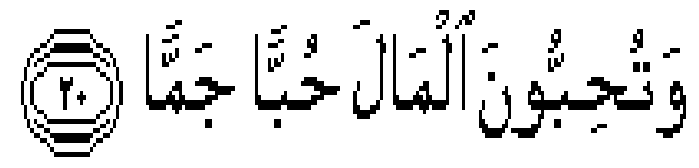

Terjemahan : Dan kamu mencintai harta benda dengan kecintaan yang berlebihan.(Putra, 1999)

Tafsir: (Dan kalian mencintai harta benda dengan kecintaan yang berlebihan) sehingga kalian merasa sayang untuk menafkahkan hartanya dijalan kebaikan. Menurut satu qiraat pada keempat Fi'il tadi, yaitu Laa Tukrimuuna, Laa Tahaadhdhuuna, Ta'kuluuna, dan Tuhibbuuna, dibaca Laa Yukrimuuna, Laa 


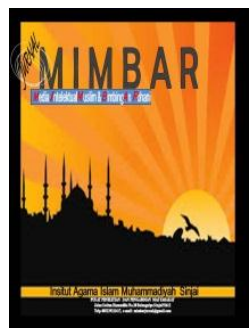

\section{MIMBAR}

Jurnal Media Intelektual Muslim dan Bimbingan Rohani

Volume 7, No. 2, 2021

ISSN (print) : 2442-3217 / ISSN (online) : 2716-3806

Email : : mimbarjurnal@gmail.com

Homepage : http://journal.iaimsinjai.ac.id/indeks.php/mimbar

DOI $\quad$ : https://doi.org/10.47435/mimbar.v7i2

Yahaadhdhuuna, Ya'kuluna dan Yuhibbuna. Makna ayat-ayat di atas berdasarkan bacaan pertama (Tafsir, n.d.).

Orang yang durhaka itu terus mencari dan mengumpulkan kekayaan tanpa mengenal lelah dan tidak peduli halal atau haram. Di samping itu, mereka sangat pelit, tidak mau mengeluarkan kewajiban berkenan harta, yaitu membayar zakat, membantu orang yang kekurangan. Allah tidak mungkin sayang kepada orang kaya raya yang memperoleh kekayaan itu dengan cara yang tidak benar. Juga kepada orang yang tidak mau membantu orang lain. Mereka mengira bahwa mereka memperoleh kekayaan itu sebagai tanda bahwa Allah menyayangi mereka, sebaliknya Allah sesungguhnya membenci mereka. Tidak mustahil mereka akan dijatuhi azab seperti yang telah ditimpahkan-Nya kepada umat-umat terdahulu. Di akhirat nanti Allah akan memasukkan mereka ke neraka. Maka pesan moral yang terkandung dalam ayat ini, memberikan peringatan kepada seseorang agar tidak mencintai harta di luar batas kewajaran.

\subsection{Eksistensi Kecenderungan Memilki Dalam Islam}

\subsubsection{Kecenderungan Memiliki Dalam Al-Qur'an}

Kata zuyyina pada surah Ali-Imran ayat 14 bermakna 'dijadikan' indah bagi manusia kecintaan kepada aneka syahwat, yakni ragam keindahan. Yang diperindah bagi manusia adalah "kecintaan" mereka kepada syahwat atau dengan kata lain kecenderungan alamiah terhadap duniawi, hal yang bersifat inderawi dan material.

Kecenderungan alamiah terhadap duniawi meliputi beberapa aspek mulai dari perempuan atau laki-laki (pasangan), anak-anak (keluarga), hingga harta seperti emas, perak, kuda, binatang ternak dan sawah ladang. Itu semua hanya di antara interpretasi dari berbagai kenikmatan dunia yang mungkin dan sering kali dicintai manusia (Shihab, 2002).

Al-Sa'adi menyebutkan dalam kitabnya, Taysir al-Karim al-Rahman Fi Tafsir Kalam al-Mannan, makna surah Ali-Imran ayat 14 adalah dihiasi bagi manusia kecintaan terhadap syahwat duniawi, yakni perempaun, anak, harta benda yang bertumpuk dalam bentuk emas dan perak, kuda pilihan, hewan ternak dan sawah 


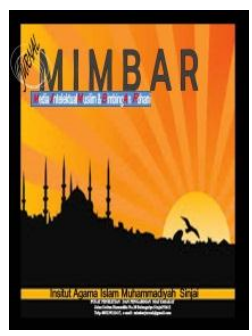

\section{Volume 7, No. 2, 2021}

ISSN (print) : 2442-3217 / ISSN (online) : 2716-3806

Email : : mimbarjurnal@gmail.com

Homepage : http://journal.iaimsinjai.ac.id/indeks.php/mimbar

DOI $\quad:$ https://doi.org/10.47435/mimbar.v7i2

ladang. Perkara-perkara tersebut mulai dari perempuan hingga lading disebutkan secara khusus karena itu semua merupakan pangkal kenikmatan duniawi yang paling besar, sedangkan selainnya hanya tambahan. Aspek-aspek inilah yang digandrungi oleh hampir setiap manusia bahkan tak jarang mereka menggilainya hingga melampaui batas (As-Sa'di, 2012).

Sedangkan Musthafa al-Maraghi menyebutkan dalam kitabnya, Tafsir alMaragih, surah Ali-Imran ayat 14 menunjukan bahwa kecintaan terhadap syahwat duniawi dianggap baik oleh manusia. Mereka tekadang tidak peduli apakah sesuatu yang dicintainya itu bain atau tidak. Akibtanya mereka tidak ingin berpaling darinya selalu ingin bersamanya. Al-Maragih, seseorang yang sudah kelewat batas mencintai syahwat duniawi tidak akan meninggalkan kecintaanya tersebut sekalipun itu tidak berharga, tidak bermanfaat, dan menimbulkan dampak negatif baginya (Al-Maraghi, 1993).

Disisi lain penyebutan anak laki-laki pada Ali-Imran 3: 14 dikarenakan masyaratkat kala itu sangan mendambakan anak laki-laki ,karena dianggap sebagai kebanggan keluarga. Dengan demikian surah Ali-Imran 3:14 bermakna dijadikan indah bagi manusia seluruhnya tanpa terkecuali, kecintaan kepada aneka syahwat duniawi, yakni wanita-wanita bagi pria, pria-pria bagi wanita, serta anak lelaki dan anak-anak perempuan. Artinya setiap manusia baik laki-laki maupun perempuan memiliki kecenderungan alamiah terhadap duniawi.

Kata al-mal yang diposisikan sebagai zinah, berfungsi sebagai perhiasan dunia yang sering membuat manusia lalai mengingat Allah. Allah menjelaskan bahwa yang menjadi kebanggaan manusia di dunia adalah harta benda dan anak-anak, karena manusia sangat memperhatikan keduanya. Banyak harta dan anak dapat memeberikan kehidupan dan martabat yang terhormat kepada orang yang memilikinya. Seperti halnya 'Uyainah, pemuka Quraish yang kaya itu, atau Qurtus yang mempunyai kedudukan mulia di tengah-tengah kaumnya, karena memiliki harta dan anak buah yang banyak. 


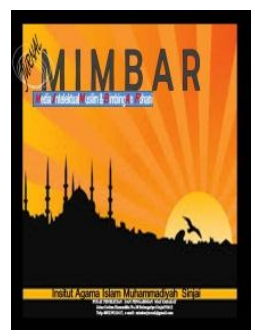

\section{MIMBAR}

Jurnal Media Intelektual Muslim dan Bimbingan Rohani

Volume 7, No. 2, 2021

ISSN (print) : 2442-3217 / ISSN (online) : 2716-3806

Email : : mimbarjurnal@gmail.com

Homepage : http://journal.iaimsinjai.ac.id/indeks.php/mimbar

DOI $\quad:$ https://doi.org/10.47435/mimbar.v7i2

Dalam urutan ayat ini, harta lebih didahulukan dari anak, padahal anak lebih dekat ke hati manusia, karena harta sebagai perhiasan lebih sempurna daripada anak. Harta dapat menolong orang tua dan anak setiap waktu dengan harta itu pula kelangsungaan hidup keturunan dapat terjamin. Kebutuhan manusia terhadap harta lebih besar dari pada kebutuhannya terhadap anak, tetapi tidak sebaliknya (Indonesia, 1995). Karena orang yang mempunyai anak, sedang dia tidak mempunyai harta, maka orang itu berada dalam kesengsaraan dan kemelaratan.

Ayat ini bukannya meremehkan harta dan anak-anak, hanya membandingkan harta dan anak-anak yang sekedar difungsikan sebagai hiasan duniawi dengan amalamal saleh. Memang harta dan anak juga dapat menjadi sarana utama untuk beramal saleh, tetapi ketika itu ia tidak boleh difungsikan hanya semata-mata sebagai hiasan duniawi, karena jika demikian ia dapat menjadi bencana.

Q.S. Al-Khafi ayat 46 menjelaskan bahwa harta dan anak-anak adalah perhiasan kehidupan dunia. Kesemuanya tidak abadi dan bisa memperdaya manusia, tetapi amal-amal yang kekal dilakukan karena Allah dengan saleh, yakni sesuai dengan tuntunan agama dan bermanfaat adalah lebih baik pahalanya di sisi Tuhanmu serta lebih baik dan dapat diandalkan untuk menjadi harapan.

Sementara kata zinah yang dipakai bermakna hiasan atau sesuatu yang dianggap bermakna hiasan atau sesuatu yang dianggap baik dan indah. Hal itu bukan tanpa alasan, karena ada unsur keindahan pada harta disamping manfaat demikian juga apada anak, karena disamping itu anak juga akan dapat membela adan membantu orang tuanya.

Penamaan kedunya sebagai zinah atau hiasan jauh lebih tepat daripada menamainya sesuatu yang berharga atau bernilai. Karena kepemilikan harta dan kehadiran anak tidak dapat menjadikan seseorang berharga atau menjadi mulia. Kemuliaan dan penghargaanya hanya diperoleh melalui iman dan amal saleh.

Harta dalam islam seungguhnya adalah wasilah atau media yang mengantarkan pemiliknya untuk mendekat kepada Allah. Sebaliknya, harta yang 


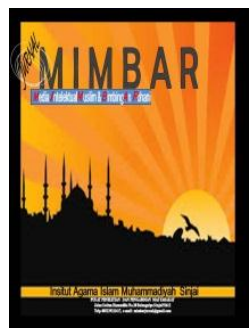

\section{MIMBAR}

Jurnal Media Intelektual Muslim dan Bimbingan Rohani

Volume 7, No. 2, 2021

ISSN (print) : 2442-3217 / ISSN (online) : 2716-3806

Email : : mimbarjurnal@gmail.com

Homepage : http://journal.iaimsinjai.ac.id/indeks.php/mimbar

DOI $\quad$ : https://doi.org/10.47435/mimbar.v7i2

tidak difungsikan untuk kepentingan sosial maka harta yang dimilikinya menjadi racun dan fitnah di dalam kehidupan (Tafsir, n.d.).

Dalam surah Al-fajr ayat 20 Ulama Ibnu Katsir menafsirkan Jammaa dengan katsiroon (banyak). Dalam Tafsir Al-Qur'an Al-Azhim 7: 563 yang artinya manusia itu sangat berlebihan dalam mencintai hartanya (Katsir, 1999). Orang yang durhaka itu terus mencari dan mengumpulkan kekayaan tanpa mengenal rasa lelah dan tidak peduli halal atau haram. Disamping itu, mereka sangat pelit, tidak mau mengeluarkan kewajiban berkenaan dengan harta, yaitu membayar zakat dan membantu orang yang kekurangan.

Allah tidak mungkin sayang kepada orang kaya raya yang memperoleh kekayaan itu dengan cara yang tidak benar juga kepada orang yang tidak mau membantu orang lain. Mereka memperoleh kekayaan itu sebagai tanda bahwa Allah menyayangi mereka.

Sebaliknya Allah sesunggunya membenci mereka tidak mustahil mereka akan dijatuhi azab seperti yang telah ditimpahkan-Nya kepada umat terdahlulu itu. Diakhirat nanti Allah akan memasukkan mereka ke dalam nereaka. Hal itu hendaknya dijadikan pelajaran oleh seluruh umat manusia (Tafsir, n.d.).

\subsubsection{Objek Kecenderungan Memilki}

Adapun objek kecenderungan memiliki dapat dilihat sebagai berikut:

1) QS. Ali-Imran 3: 14

Dalam surah Ali-Imran kecenderungan memiliki dapat digambarkan seperti Kecintaan Terhadap Wanita, wanita menempati urutan pertama karena kecintaan dunia adalah kenikmatan yang tertinggi dan paling sempurna. Namun, ayat ini juga menandakan bahwa yang diamksud wanita adalah juga pria. Maksudnya adalah pria mencintai wanita dan wanita mencintai pria. Kecintaan Terhadap Anak Laki-Laki meski ayat ini secara jelas menegaskan bahwa yang dijadikan indah bagi manusia adalah kecintaan terhadap syahwat yang berupa anak laki-laki, namun bukan berarti perempuan tidak termasuk. Anak apapun jenis kelaminya adalah salah satu hal yang dimaksud dalam ayat ini. (Pada poin sebelumnya memang tidak disebutkan secara 


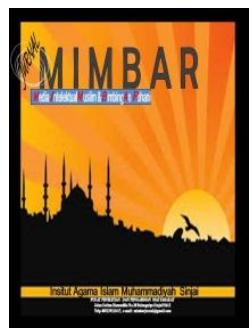

\section{MIMBAR}

Jurnal Media Intelektual Muslim dan Bimbingan Rohani

Volume 7, No. 2, 2021

ISSN (print) : 2442-3217 / ISSN (online) : 2716-3806

Email : : mimbarjurnal@gmail.com

Homepage : http://journal.iaimsinjai.ac.id/indeks.php/mimbar

DOI $\quad$ : https://doi.org/10.47435/mimbar.v7i2

terang kata pria yang disebut hanya wanita, namun disebutkanya anak laki-laki pada poin ni mewakili hal itu. Juga tidak disebutkannya anak perempuan pada ayat ini telah terwakili oleh kata "wanita" pada poin sebelumnya). Kecintaan Terhadap Harta Yang Banyak dan Jenis Emas Dan Perak, kedua hal ini dicintai karena mencakup harga semua hal. Siapa yang memilki keduanya berarti memilki semua hal. Menurut penulis yang perlu dipahami dalam konteks sekarang adalah semua harta masuk pada kategori ini tidak hanya emas dan perak. Kecintaan Terhadap Kuda Pilihan kuda-kuda pilihan akan mendukung bisnis dan perniagaan pemiliknyajuga mereka yang memilki kuda-kuda pilihan akan bersaing dan membanggakan diri "melawan" kawan-kawanya. Begitu penjelasan dalam tafsir Al-Maraghi. Dari konteks ini menurut penulis jika dikaitkan pada konteks sekarang agaknya kendaraankendaraan mewah atau armada bisnis juga termasuk di dalamnya. Kecintaan Terhadap Binatang-Binatang Ternak, yang dimaksud binatang-binatang ternak di sini adalah onta, sapi, dan domba yang digunakan untuk menghasilkan harta yang bisa berkembang. Begitu penjelasan dari al-Qasimi dalam Mahasin al-takwil. Dari sini penulis memahami bahwa apapun yang berpotensi menghasilkan harta yang berkembang masuk dalam kategori ini. Kecintaan Terhadap Sawah Ladang ditempatkan diakhir karena menghasilkan suatu tanah agar bisa disebut sawah ladang tidak bisa instan. Harus melewati proses yang tidak sedikit dan tidak sebentar. Terlepas dari semua itu apapun yang dimilki seseorang sejatinya adalah bentuk ujian dari Allah (Shihab, 2006).

2) QS. Al-Khafi 18: 46

Dalam surah Al-Khafi kecenderungan memiliki dapat digambarkan kebanggan terhadap harta yang dimilki yaitu manusia yang sangat membanggakan harta yang dia milki dan mereka menyangka dengan hartanya yang banyak dikumpulkan akan menjadi jaminan untuk kekal hidupnya di dunia dan lepas dari perhitungan Allah di akhirat, kebanggan terhadap anak-anak yaitu manusia yang sangat membanggakan anak-anak mereka dan menggap bahwa, kebanggan terhadap perhiasan kehidupan mereka mengira bahwasanya harta yang mereka dapatkan adalah 


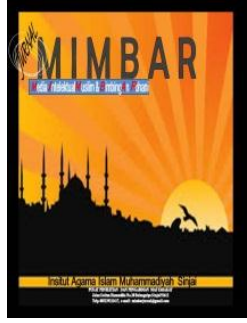

\section{MIMBAR}

Jurnal Media Intelektual Muslim dan Bimbingan Rohani

Volume 7, No. 2, 2021

ISSN (print) : 2442-3217 / ISSN (online) : 2716-3806

Email : : mimbarjurnal@gmail.com

Homepage : http://journal.iaimsinjai.ac.id/indeks.php/mimbar

DOI $\quad:$ https://doi.org/10.47435/mimbar.v7i2

usahanya semata, fadahal hakikatnya harta adalah anugerah Allah, kebanggan terhadap dunia. Tetapi amal saleh lebih baik di sisi Allah serta lebih baik menjadi harapan.

3) QS. Al-Fajr 18: 20

Dalam surah Al-Fajr kecenderungan memiliki dapat digambarkan cinta yang berlebihan kepada harta benda, ia juga mengandung arti cinta yang keji dan perbuatan kotor (Katsir Ad-Dimasyqi, 2001). Orang yang durhaka itu terus mencari dan mengumpulkan kekayaan tanpa mengenal lelah dan tidak peduli halal atau haram. Jadi, kebanggan terhadap harta merupakan tabiat manusiawi, namun bahwasanya harta itu tidak dijadikan sebagai kebanggaan yang melewati batas kewajaran.

\subsubsection{Bentuk-bentuk Kecenderungan Memiliki}

1) Dalam bentuk benda:

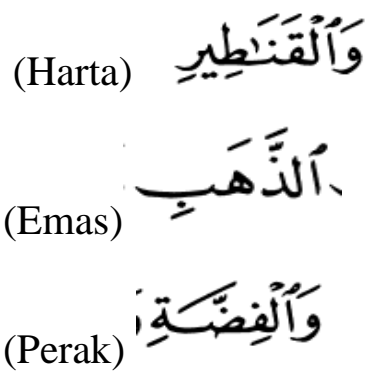

(Perhiasan Kehidupan)

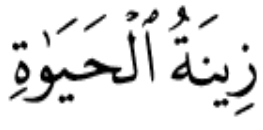

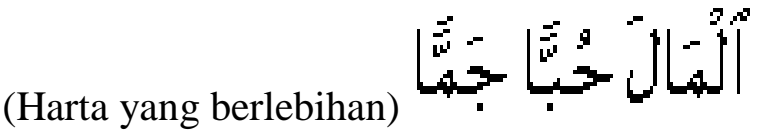

2) Dalam bentuk makhluk:
(Wanita- wanita)

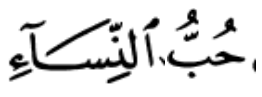

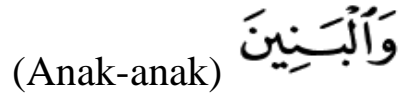
(Kuda Pilihan)

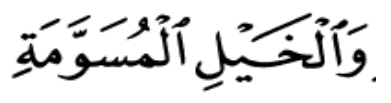




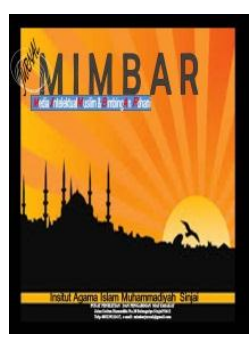

\section{Volume 7, No. 2, 2021}

ISSN (print) : 2442-3217 / ISSN (online) : 2716-3806

Email : mimbarjurnal@gmail.com

Homepage : http://journal.iaimsinjai.ac.id/indeks.php/mimbar

DOI $\quad:$ https://doi.org/10.47435/mimbar.v7i2

(Binatang Ternak)

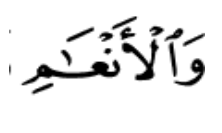

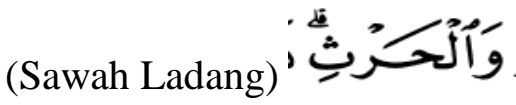

\subsubsection{Implementasi Kecenderungan Memiliki}

Manusia pada dasarnya memiliki kecenderungan terhadap dorongan insting sosial untuk menyukai, menguasai, dan mempertahankan harta bendanya. Kecintaan manusia terhadap harta ini harus mendapatkan bimbingan yang mengarahkan bahwa harta bukan tujuan hidup, akan terapi hanya sebagai sarana yang harus dipertanggung jawabkan kepada Allah (Munawaroh, 2019).

Harta merupakan salah satu amanah yang diberikan Allah kepada manusia yang harus disyukuri dalam parameter nilai-nilai Islami. Dalam Islam dijelaskan bahwa harta sebenarnya adalah hakikatnya milik Allah SWT manusia hanyalah pemegang amanah saja. Allah-lah pemilik harta benda, karena yang menciptakannya dan yang menciptakan sumber produksinya serta memudahkan sarana untuk mendapatkannya, bahkan Allah juga yang menciptakan manusia dan seluruh alam semesta. Kemudian setelah itu barulah terjadi proses pemindahan kepemilikan yang di dasarkan kepada aturan-aturan Allah SWT. Harta tersebut diamanatkan kepada manusia sebagai kholifah dimuka bumi agar mau menjaga dan memanfaatkannya dijalan yang sudah digariskan oleh Allah sesuai dengan syariat.

Oleh karena itu konsep hak kepemilikan harta dalam Islam sebenarnya adalah bukanlah milik manusia, akan tetapi milik Allah dan akan kembali kepada Allah. Manusia dibolehkan memiliki harta akan tetapi dengan syarat cara memperoleh dan memanfaatkan harta tersebut sesuai dengan perintah Allah. Jadi, manusia terhadap harta adalah:

a) Bukan pemilik asli

Manusia bukanlah pemilik asli dari harta yang dimilki, Allah lah sebagai pemilik asli dari harta yang dimiliki oleh manusia.

b) Hanya sebatas pemegang amanah 


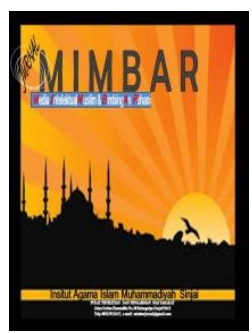

\section{Volume 7, No. 2, 2021}

ISSN (print) : 2442-3217 / ISSN (online) : 2716-3806

Email : mimbarjurnal@gmail.com

Homepage : http://journal.iaimsinjai.ac.id/indeks.php/mimbar

DOI $\quad$ : https://doi.org/10.47435/mimbar.v7i2

Manusia hanyalah pemegang amanah dari harta yang dimiliki oleh manusia.

c) Manusia menerima harta sebagai rizki.

Ketika didunia harta dimakan, dipakai, ditempati, dan digunakan. Dan diberikan kepada orang-orang yang memburuhkan bantuan.

\section{Penutup}

Milk didefenisikan sebagai kekhususan terhadap pemilik suatu barang menurut syara' untuk bertindak secara bebas bertujuan mengambil manfaatnya selama tidak ada penghalang syar'i. Kepemilikan berarti hubungan syariah antara manusia dengan sesuatu (harta) yang memberikan hak mutlak kepada orang itu untuk melakukan pemanfaatan (tasharruf) atas sesuatu itu dan mencegah orang lain memanfaatkannya. Ketergantungan seseorang dikarenakan setiap manusia mempunyai kebutuhan. Kebutuhan yang harus dipenuhi oleh ekonomi itu berbeda dari masyarakat yang satu ke masyarakat yang lain, dari orang yang satu ke orang yang lain. Perbedaan itu disebabkan oleh berbagai faktor,salah satunya sesuai kebutuhan Ajaran Islam merupakan ajaran yang sempurna mencakup seluruh kehidupan maka kita wajib berpendirian bahwa Islam sebagai agama yang telah menggariskan prinsip-prinsip kehidupan mencakup berbagai aspek, termasuk aspek kecenderungan memilki.

Dalam al-Qur'an menjelaskan mengenai konsep harta adalah konsep harta menurut beberapa mufassir pun telah dijelaskan di dalam bukunya. Seperti pendapat Muhammad Sirrin dan Qatadah mengemukakan bahwa sebagian harta adalah hak fakir miskin, yang karenanya diwajibkan untuk berzakat. Ibnu Abbas pun berpendapat, bahwa sebagian harta yang hak buka hanya sekedar berzakat, melainkan menyisihkan sebagian harta untuk fakir miskin (tidak hanya pada waktu zakat). Sejatinya semakin tinggi tingkat intelektualitas seseorang, maka semakin sedikit tenaga yang harus dikeluarkan untuk mendapatkan harta yang dibutuhkannya. Begitulah gambaran tentang kecenderungan memiliki yang tidak pernah habis bila dikupas dalam berbagai aspeknya. Pada dasarnya harta adalah hakikatnya milik Allah 


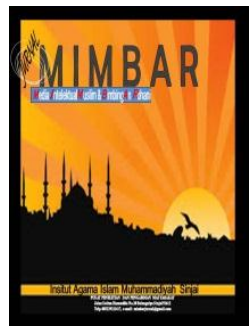

\section{MIMBAR}

Jurmal Media Intelektual Muslim dan Bimbingan Rohani

Volume 7, No. 2, 2021

ISSN (print) : 2442-3217 / ISSN (online) : 2716-3806

Email : : mimbarjurnal@gmail.com

Homepage : http://journal.iaimsinjai.ac.id/indeks.php/mimbar

DOI $\quad$ : https://doi.org/10.47435/mimbar.v7i2

yang diamanatkan kepada manusia. Manusia boleh memiliki harta meskipun banyak, akan tetapi manusia ketika memperoleh harta dan memanfaatkan harta harus dengan cara yang baik. Dalam memperoleh harta dilarang menjalankan sebab-sebab yang diharamkan seperti, riba, mencuri, curang. Sedangkan dalam memanfaatkan harta seperti memenuhi kewajiban zakat, infaq, sedekah. Demikian itu akan mewujudkan kehidupan yang sejahterah.

\section{Daftar Pustaka}

Al-Maraghi, A. M. (1993). Tafsir Al-Maraghi. Toha Putra.

Al-Zarqa, M. A. (1968). Al-Madkhal al-Fiqh al-Islami. In Damascus: Dar al-Fikr.

Al-Zuhaily, W. (1989). al-Fiqh al-Islamiy wa Adillatuhu. Juz VII, Damsyiq: Dar AlFikr.

As-Sa'di, S. A. bin N. (2012). Taysir Al-Karim Ar-Rahman Fi Tafsir Al-Kalam AlMannan. Darul Haq.

HD, K. (2000). Islam dan Aspek-aspek Kemasyarakatan. PT Bumi Aksara.

Indonesia, D. A. R. (1995). Al-Qur'an dan tafsirnya. Jlid I-X, Universitas Islam Indonesia, Yogyakarta: PT Dana Bhakti Wakaf.

Katsir Ad-Dimasyqi, I. (2001). Tafsir Ibnu Kasir Juz 8 (P. B. A. Bakar (ed.)). Sinar Baru Algensindo.

Katsir, I. (1999). Tafsir al-Qur'an al-Adzim. Cairo: Dar Al-Tiba'ah Wa AlTaudzhi.

Kementerian Agama, R. I. (2014). Al-Quran dan Terjemahnya. Jakarta: PT. Hati Emas.

Mannan, A. (1993). Ekonomi Islam: Teori dan Praktek. PT. Dana Bhakti Wakaf.

Munawaroh, Z. (2019). Harta Dan Hak Kepemilikan Dalam Perspektif Al- Qur'an. Universitas Islam Negeri Sunan Ampel Surabaya.

Putra, T. (1999). Al-Qur'an dan Terjemahnya. Semarang: Departemen Agama Republik Indonesia.

Qalaji, M. R., Qunaybi, H. S., \& Sanu, Q. M. (1996). Mu’jam Lughat Al-Fuqaha (dictionarry of Islamic Legal Terminolgy): Arabic-English-French. Dar AnNafes.

Qordaw, Y. (2007). Norma dan Etika Ekonomi Islam. Gema Insani Pers.

Shihab, M. Q. (2002). Tafsir al-misbah. Jakarta: Lentera Hati, 2.

Shihab, M. Q. (2006). Wawasan Al-Quran (Tafsir Maudhu'i atas Pelbagai Persoalan Umat) (Cet. XVII). Mizan.

Tafsir. (n.d.). Tafsir learn quran. Tafsir.Learn-Quran.Co. Retrieved October 20, 2021, from https://tafsir.learn-quran.co/id/surat-3-al-imran/ayat-14

Wiranegara. (1988). Ekonomi dan Keuangan Makna Ekonomi Islam. PT Gita Karya.

MIMBAR : Jurnal Media Intelektual Muslim dan Bimbingan Rohani

Clicensed under a Creative Commons Attribution-ShareAlike 4.0 International License 